\title{
THE MYSTERIOUS RELATIONS TO THE EAST LIN MA
}

Scholars who focus on Heidegger's Asian connection have made highly positive claims with respect to his stance towards a dialogue with the East. However, some of their arguments are based on taking-for-granted literal readings of a few phrases and passages from Heidegger's corpus without regard to the context of their appearance. These authors include: J.L. Mehta, a pioneer explorer of the implications of Heidegger's thought with respect to East-West dialogue; R. May, whose work became better known through G. Parkes' English translation; and a number of scholars whose contributions are mainly published in German, such as F. Vetsch, who attributes to Heidegger an account of intercultural confrontation (Auseinandersetzung), W. Hartig, according to whom Heidegger has initiated a dialogue with "the few other great beginnings" (that is, for him, "the Indian and Sino-Japanese world"), and K.K. Cho, who considers Heidegger's phrase "the mysterious relations to the East" in the "Letter on Humanism" to be a piece of incontestable testimony that Heidegger has deliberately adopted Laozi's thinking in that essay.

The purpose of this paper is primarily "deconstructive". It aims to demonstrate how the relevant phrases and remarks have been misread and misused as the basis for establishing apparently exciting but actually unwarranted claims with respect to Heidegger's connection with intercultural dialogue. In the meantime, through meticulous analysis of Heidegger's texts, I suggest convincing readings in light of both the immediate textual context and the broad context of Heidegger's Denkweg. I believe that clearing up the labyrinthine ground for properly deciphering his texts can help us find a better orientation in accordance with which we can obtain a firm grasp of Heidegger's comportment towards East-West dialogue. Heidegger scholars, in the sense of those philosophers whose attention is devoted to his corpus as such and who have almost never attempted to delve into the intricate issue of his connection with Asian thought, have not yet subjected those relevant passages, to which I call attention, to meticulous and careful analyses. This is another reason that justifies their close examination.

In writing the present paper I assume general familiarity with major themes and ideas of Heidegger's philosophy, for example, the fundamental importance he attributes to the role of Greece, his idea that philosophy is Greek in its nature and origin, and his notion of Anfang (beginning) and the Ge-stell, the first beginning and the other beginning. In another study I have covered most of these themes and offered a preliminary assessment of Heidegger's attitude towards East-West dialogue. ${ }^{1}$ The focus of this paper falls 
upon presenting scrupulous exegeses of a number of Heidegger's remarks that have been cited as evidence for his concern with intercultural dialogue.

First, I argue that such words as Morgenland, Orient, Ost, and Asien, which Heidegger employs on a number of occasions, refer to Greece. One cannot identify them with Asia or East Asia in the ordinary sense. In "Anaximander's Saying" from 1946, ${ }^{2}$ Heidegger uses the phrase "Occident and Orient" in relation to the Abendland and "the European"; in the "Letter on Humanism" (1946), he speaks of "the mysterious relations to the East" with reference to Hölderlin's poems. ${ }^{3}$ I argue that on both of these occasions, Heidegger's fundamental concern is, again, with Greece, the East par excellence. One cannot take Heidegger's remarks to be unequivocal testimony for his concern with the relation between the contemporary West and Asian traditions. Further, most commentators have unquestioningly identified the phrase "the few other great beginnings" in the essay "Hölderlin's Earth and Heaven" (1959) with East Asian thought. ${ }^{4}$ Through a careful examination of that text, I explicate that the most plausible referent of this phrase is the four-fold, that is, earth, heaven, god and man. They are inextricably related to Greece, where the first beginning of philosophy originated.

\section{Hölderlin, the Foreign and the Morgenland}

It is well known that Hölderlin's poetry has played an important role in the thinking of the later Heidegger. He insists that his elucidations (Erläuterungen) on these poems stem from a dialogue of his thinking (Denken) with the poet's poetizing (Dichten), from the necessity of thinking (EHP 21/7). Furthermore, Heidegger reads into Hölderlin's poetry a central concern with the history of Being and the destiny of the world, and claims that Hölderlin's thinking is of a world-historic nature and is therefore more originary and essential for the future than that of any other literary figure. On the same basis, Heidegger attributes to the poet's oeuvre a special relation with the Greek world. ${ }^{5}$ In this connection, he discerns a theme of a "journey to the foreign" (Wanderschaft in die Fremde) in the latter's verses and expounds them in this way, as they sit well with his own philosophical orientation.

We should notice that the word 'the foreign' (das Fremde), as connected with the theme of the "journey to the foreign", refers to Greece. Some commentators have considered this theme to be an unambiguous account of intercultural dialogue. For example, Peter Trawny suggests that the "historical" (geschichtliche) dimension of the "foreign" is "interculturality". 6 Florian Vetsch reads into Heidegger's thematization of the "journey to the foreign" a scheme of intercultural encounter that consists in "two-and-a-half" steps; he seems to treat "the foreign" as an indeterminate conceptual construct. ${ }^{7}$ These presumptions proceed from an inaccurate understanding of Heidegger's usage of the word 'the foreign', which in fact designates Greece. 
In the essay "Hölderlin's Poetry: a Destiny" written in 1945-46, Heidegger writes,

The foreign, however, is in the first place, as it is for all essential poets from the Abendland, Greece. Hölderlin often says 'Asia'. ... The rising water, the mouth, which calls, - that [is what] the source follows. To the East and back. From there the Danube, homely stream; "Der Ister". From Asia to Europe, from Morgenland to the Abendland, "from land to land" ....

Heidegger explicitly states that "the foreign" refers to Greece. ${ }^{9}$ From the same passage, it is also clear that Morgenland, Asien (Asia) and Ost (East) in Heidegger's usage do not refer to Asia in the current sense, but signify Greece as well.

In the nineteenth century, Germany is regarded as the Abendland (Eveningland; Occident), while Morgenland (Morning-land; Orient) signifies everything that is not part of Germany. For example, Nietzsche once remarks that the Greeks provided the synthesis of everything morgenländisch and "the beginning of the European soul." ${ }^{10}$ This tradition may be what Heidegger and Hölderlin have in mind in calling Greece the Morgenland. Confusions are exacerbated when Morgenland is translated into English as "Orient" or "antiquity". For example, in "Hölderlin's Earth and Heaven" (1959), Heidegger writes: "The humble is the occidental. Greece, however, the oriental [das Morgenländische], is the great beginning that may possibly come" (EHP 200/176). When translating one of Heidegger's lecture courses on Nietzsche, David Krell renders morgenländische Geschichte as "the history of antiquity". ${ }^{11}$

Heidegger ascribes originary significance to the Morgenland. The Morgenland is where Western destiny and philosophical tradition came into birth. For instance, in the lecture course on Parmenides delivered in 1942-43, Heidegger observes,

according to this essential origination of $\dot{\alpha} \lambda \dot{\eta} \theta \varepsilon \imath \alpha$, the Evening-land [Abendland] is the not yet decided or delimited landscape of the earth upon which an evening is descending, which as evening essentially takes its beginning from the dawn and therefore harbours in itself the morning of this landscape. (P 147/219) ${ }^{12}$

An evening takes its beginning from the dawn, therefore the Evening-land (the West) embodies in itself the Morning-land, both having world-historic significance. The Morgenland is indispensable for the transformation of the West, the Abendland.

\section{The "Occident and Orient"}

Heidegger refers to Greece as the "Orient" as well. In his essay "Anaximander's Saying" written in 1946, Heidegger raises such a question: "Will this Evening-land [Abend-Land] rising above the Occident and Orient [Orient] and transcending the European, become the place of the coming, more primordially destined, history?" (A 245/326) (13 $^{13}$

J. L. Mehta is perhaps the first author who noticed this passage. He draws on it for his account of Heidegger's "planetary thinking", which allegedly 
seeks "a new beginning of thought [...] beyond Orient and Occident, and [is] for the first time truly world-historical." ${ }^{14}$ On the basis of the same passage, R. Ohashi ascribes to Heidegger the view that the "Morning-land", that is, the Greek world, can only be reached "via East Asia" ${ }^{15}$ Cho explains Heidegger's question as "whether or not the trail leads through to [the source] via two different continents, namely across the Occident and the Orient - instead of the Occident alone". ${ }^{16}$ Obviously, all these three authors have taken for granted that the word "Orient" in this passage literally signifies Asia or East Asia in the customary sense.

Heidegger makes the relevant remark in the context of reflecting upon the essence of the West from out of "that of which the early saying speaks" (A 245/326). According to Heidegger, "the antiquity which conditions Anaximander's saying belongs to the dawn of the dawn of the land of the Evening" (A 246/327). The Evening-land, that is, the West, is the historical topos where Anaximander's saying is heard. The word 'Orient' in the cited passage most probably refers to Greece, and the Occident seems to be distinct from the Orient in terms of a different comportment towards Being. It is connected with a totalitarian approach to Being that is made possible precisely by the inner necessity of Being itself, and it has become Europe in the present epoch. ${ }^{17}$ Despite its difference from the Orient, if it retraces its own origin and truth, the Occident will find that it belongs essentially and historically to both the Orient (Greece) and the Evening-land (the West), which is the nearness to the source. When the Occident achieves homecoming from a journey to the Orient (that is, Greece), the newly commenced dawn will hopefully emerge in the Evening-land. Only the Evening-land enjoys a "historical nearness" (geschichtliche Nähe) to what is spoken in the early saying of Anaximander, which will speak out in that which is coming. In the same vein, Heidegger speaks of "destiny [Geschick] leading spirit [Geist] in its wandering from the Orient into the Occident" in the essay Das Abendländische Gespräch. ${ }^{18}$ Compare also another passage written in the same period as "Anaximander's Saying": "We, the poets; the word, that which destiny has sent us, that which is to be said says, that which unifies Asia and Europe, Morgenland and Abendland, while it 'is' 'above' them, only [thus] supporting and enabling their hidden historic essence."

It is obvious that in this context Asia does not refer to what is usually considered as Asia, but to Greece. That the word is "above" Asia and Europe, above Morgenland and Abendland, is similar to the saying in the preceding passage with respect to the Evening-land being "above" Occident and Orient. The incipient word in the dawning of philosophy is what unites Morgenland (that is, Greece) and Abendland; at the same time, it is above both of them. This means that there is something inexhaustible with the word, and with Morgenland and Abendland. This inexhaustible something is what constitutes the historic essence of the latter two. 


\section{The Mysterious Relations to the East}

Another misinterpreted phrase is "the mysterious relations to the East" (die geheimnisvollen Bezüge zum Osten), which appears in the "Letter on Humanism" composed in 1946, where Heidegger states, "we have still scarcely begun to think of the mysterious relations to the East that have come to word in Hölderlin's poetry" (LH 257/338). Cho considers that the essay "Letter on Humanism" was composed under the immediate impact of the ancient Chinese scripture Daodejing whose verses Heidegger attempted to translate in collaboration with a Chinese scholar in the summer of $1946 .{ }^{19} \mathrm{He}$ invokes Heidegger's reference to the thought-worthiness of the "mysterious relations to the East" as a piece of incontrovertible evidence for the special connection of "Letter on Humanism" to Laozi or dao, although, as he acknowledges, neither of these two words appear in letter in this essay. ${ }^{20}$ It is clear that Cho takes the word 'East' to be a reference to the East in the contemporary common usage. However, we have to understand Heidegger's phrase from the context of his writings.

In observing that "we have still scarcely begun to think of the mysterious [geheimnische] relations to the East that have come to word in Hölderlin's poetry" in the "Letter on Humanism", Heidegger refers to Hölderlin's poems "The Ister" and "The Journey". He may bear in mind such words as "East" and "journey to the foreign" that occur in Hölderlin's poems. In "The Ister", Hölderlin sings,

He [the Ister] appears, however, almost

To go backwards and

I presume he must come

From the East [Osten]. ${ }^{21}$

In the beginning of his elucidation on Hölderlin's "Remembrance", written in 1943, Heidegger makes a connection between "coming from the East" and a seemingly empirical observation. Istros (Ister) is the Greek name for the lower course of the Danube. Heidegger notes the fact that near to its source the Danube sometimes stops and even goes back, forming whirlpools. From this observation he imagines that the river Ister comes from the place where it flows into the "foreign sea" and that it "belongs to the foreign land of the East" (in die Fremde des Ostens gehört) (EHP 106/79; em. ad.). That "the East" refers to Greece is most clearly shown in the following, already cited passage:

The foreign, however, is in the first place, as it is for all essential poets from the Abendland, Greece. Hölderlin often says "Asia". ... The rising water, the mouth, which calls, - that [is what] the source follows. To the East and back. From there the Donau, homely stream; "Der Ister". From Asia to Europe, from Morgenland to the Abendland, "from land to land" .... (HDG, 357)

In this passage, there are resonances with the suggestion that "coming from the East" means that the Ister "belongs to the foreign land of the East". It is immediately after asserting that 'the foreign' is Greece that Heidegger uses 
such terms as that 'Asia' and 'East'. Obviously, both these words, like 'the foreign', refer to Greece. "To the East and back": this means that contemporary Western Dasein should retrieve the resources that remain unexplored in the Greek beginning of history and philosophy and, by means of this, truly dwell in what is granted to it as its historical destiny.

Occasionally, following Hölderlin, Heidegger refers to India in terms of the 'East'. For example, he remarks that in the beginning of the concluding stanza of "Remembrance", Hölderlin "points beyond Greece towards the more distant East, towards the people of India" (EHP 108/83). I, however, agree with Bernasconi when he claims that Heidegger has tried to diminish, or to efface Hölderlin's evocation of the role of Asia (and the East, for this matter). ${ }^{22}$ Elsewhere I discuss Heidegger's use of the expression "confrontation with the Asiatic", which occurs several times in the 1930s and once in the 1960s. ${ }^{23}$

In addition, Heidegger's choice of the word geheimnisch (mysterious) may not have been unintentional. In this word one can find Heim, which means 'home, dwelling-place'. Given the importance he attaches to the 'homeland' (Heimat), to the place of the origin of the history of Being (that is, Greece), he may have deliberately chosen the word geheimnisch. Immediately preceding the occurrence of "the mysterious relations to the East", he is talking about the 'homeland'. Thought in terms of the history of Being, the word homeland means "nearness to the source" (LH 257/338). In the meantime, the West (Abendland) should be understood from out of nearness to the source. Relative to this statement, Heidegger remarks: "We have still scarcely begun to think of the mysterious relations to the East ...". Therefore, Heidegger's primary concern, again, is with Greece, the East par excellence.

\section{The First and the Other Beginning}

Before I proceed to address the issue of 'the few other great beginnings', I will introduce Heidegger's central notions of the first and the other beginning. According to Heidegger, the Greeks' experience of the truth of Being initiated the first beginning of philosophy. It is up to the contemporary Western people, who enjoy the same lineage with the Greeks, to attend to what has been said but has not yet been fully articulated and thus opens up the other beginning. Heidegger explicitly claims that the first beginning can only occur to "a historical people of thinkers and poets in the West" (P 77/114), and that "epocally speaking, the beginning of the epoch of Being lies in what we call "the Greek"' (A 255).

Heidegger distinguishes the words Anfang and Beginn. According to him, Beginn (commencement) has to do with the debut and the emergence of thinking. In contrast, Anfang (beginning, or inception) is "what, in this early thinking, is to be thought and what is thought" (P 7/9-10). This means, "Being is the beginning" (7/11). Not every thinker, who has to think Being, thinks the 
beginning, while a primordial thinker is one who expressly thinks the beginning. Etymologically speaking, the German word Anfang derives from an- (in, at, to) and -fangen (to seize, take, catch). This supports Heidegger's claim that primordial thinkers do not rely on their own resources in carrying out the beginning of thinking. Instead, they are seized and taken up by the beginning. In his own words, "The thinkers are begun by the beginning, incepted [An-gefangenen] by the in-ception [An-fang]; they are taken up by it and are gathered into it" (P 7-8/11).

In the Contributions to Philosophy, Heidegger uses the archaic word Beyng [Seyn], instead of Being [Sein], "to indicate that Being [Sein] is no longer thought metaphysically" (CP 307/436). ${ }^{24}$ Beyng is Sein in the grounding and originary sense. However, taken Heidegger's philosophy as a whole, it could be said that these two words identify two modalities of Being, or Beyng, or , no matter what word is employed. According to Heidegger, Greek thought generates from an original experience of the truth of Beyng, of the presencing that belongs to Beyng, and also of its occurrence as withdrawal. The Greek word for truth, a-lètheia, which Heidegger translates as "unconcealment", points to the dual aspect of the truth of Beyng. "Unconcealment" indicates the pre-existing experience of concealment. However, although the Greeks experienced concealment, they failed to conceive it as essentially belonging to the truth of Beyng. This does not mean that Greek thought is imperfect or disabled. Rather, the failure derives from a necessity of the history of being that determines the mode in which the truth of Beyng enacts itself in the first beginning..$^{25}$

The other beginning "helps the first beginning to [enter unto] the truth of its history - and thus unto its inalienable and ownmost otherness" (CP 131/187). Heidegger stresses an intrinsic connection between the only first and other beginning. The other beginning is only possible in accordance with its essential connection with the first beginning. Moreover, the manner of thinking in the transference from one beginning to the other is also dependent upon the 'allotment' of the first to the other beginning. On the second page of the Contributions Heidegger states,

The "other" beginning [Der andere Anfang] of thinking is named thus, not because it is simply shaped differently from any other arbitrarily chosen hitherto existing philosophies, but because it must be the only other beginning according to the relation to the only one and first beginning [er der einzig andere aus dem Bezug zu dem einzig einen und ersten Anfang sein muss]. The style of thoughtful mindfulness in the crossing from one beginning to the other is also already determined by the allotment [Zugewiesenheit] of the one beginning to the other beginning. (CP 4/5)

One should comprehend such words as 'beginning', 'first', and 'other' originarily. Do the first and the other beginning represent two beginnings respectively, or are they inextricably intertwined with one another such that speaking of them as separate terms would already miss Heidegger's point? Notably, Heidegger has never spoken of a/the second beginning. He explains 
that the other beginning is named thus "because it must be the only other out of the relation to the only one and first beginning". ${ }^{26}$ This implies that the first and the other beginning designate one single event. In the most originary sense, one could say that there is only one beginning. The 'only one' beginning grounds the space where 'the first beginning' and 'the other beginning' enact themselves in the movement of the playing-forth. The sense of the 'one' conforms to the sense in which there is only one first beginning and only one other beginning.

\section{What are "the Few Other Great Beginnings"?}

In the lecture "Hölderlin's Earth and Heaven" delivered at the meeting of the Hölderlin Society in Munich on 6 June 1959, Heidegger makes a remark in which the phrase "the few other great beginnings" (die wenigen anderen grossen Anfänge) appears. Almost all the scholars who have touched on the question of Heidegger's relation with East Asian thinking or of his thinking on intercultural dialogue in general have attached great importance to this remark. J.L. Mehta is perhaps the first scholar who commented on it. He considers that Heidegger's mention of "the few other great beginnings" involves an encouragement for the West not to remain in isolation. ${ }^{27}$ In recent years, G. Parkes, editor of the well-known collection Heidegger and Asian Thought, calls attention to this passage, ${ }^{28}$ and his view has been the most influential. He discerns in it a positive attitude towards East-West dialogue. To cite his own words, "the opening anticipated here must at the very least be an opening to the 'great beginning' of East Asian thought, wherever one locates it". ${ }^{29}$ Without a doubt, Parkes considers that "the few other great beginnings" unequivocally refer to other philosophical traditions, especially to East Asian thought.

Citing the same passage from "Hölderlin's Earth and Heaven", F. Vetsch reads it as speaking of "the necessity of the intercultural encounter for the other beginning". ${ }^{30} \mathrm{He}$ claims that this passage is of "central significance" to the theme of his book, which reads Heidegger's thought as a beginning of intercultural discussion/confrontation (Auseinandersetzung). R. Thurnher comments on the same passage in which occurs the phrase "the few other great beginnings": "Heidegger seemed to think that only in the dialogue of reflecting thought with non-western ways of thinking, would the possibility appear of founding a changed destiny of the world". ${ }^{31}$ According to W. Hartig, in making the relevant remark in "Hölderlin's Earth and Heaven", Heidegger is articulating "his vision of a thinking dialogue [Zwiesprache] of the Western world [das Abendland] with the few other great beginnings (i.e. the Indian and Sino-Japanese world)".$^{32}$ He tries to strengthen his point in saying, "the call for this dialogue of the great beginnings with each other could not be formulated more explicitly." ${ }_{33}$ All these authors seem to entertain no doubt as to the reference of "the few other great beginnings." ${ }_{34}$ 
Pöggeler does not explicitly identify "the few other great beginnings" with East Asian traditions. ${ }^{35}$ However, he does speak of "the beginnings [Heidegger] finds for the West in Greece and for the Far East in Lao-tzu". ${ }^{6}$ Bernasconi is perhaps the only scholar who has expressed serious doubts concerning Heidegger's reference to "the few other great beginnings". He senses that the suggestion that this phrase represents a plurality of beginnings,

$\ldots$ is not readily reconciled with any of the prominent interpretations of Heidegger's other texts, leaving the question as to how to construe it as anything more than an anomaly, particularly given his repeated claim that the technological world can only be addressed by the European tradition, because only it has the same source and vocation. ${ }^{37}$

However, Bernasconi has not attempted to offer a more reasonable and reliable interpretation of this perplexing passage from "Hölderlin's Earth and Heaven". In the following pages I provide an explication of "the few other great beginnings" on the basis of a reading of Heidegger's ambiguous text.

"Hölderlin's Earth and Heaven", an essay that remains an understudied writing, is an elucidation of Hölderlin's poem "Greece". This poem derives from Hölderlin's trip to Southern France, where he was made "more familiar with the authentic essence of the Greeks", as he wrote himself in a letter in 1802 to a friend (namely, Böhlendorff) after he returned home (EHP 183/157). Heidegger states, "we are bound to listen to the poem in terms of that which concerns us in the present age" (182/156). Thus, his essay is a listening to what Hölderlin sings about Greece from within the contemporary world. Citing Hölderlin's statement in the letter mentioned above, "all the holy places of the earth are together around one place, and the philosophical light around my window is now my joy", Heidegger provides a highly speculative elaboration of earth and heaven:

Through the place in which the poet now dwells, the earth becomes for him earth in a new way. The earth, as the structure of the heavenly ones, shelters and supports the holy, the sphere of the god. The earth is earth only as the earth of heaven; the heaven is heaven only insofar as it acts downward upon the earth. (EHP 186/161)

Earth and heaven have an inherent relation. They belong together in a rich relation in which they receive determination. The earth shelters the sphere of the god. In this passage, three elements out of the four of the four-fold appear. Following this, Heidegger associates the phrase "philosophical light" in Hölderlin's poem with Greece, because for him the name philosophia implies that the 'philosophical' arises from Greece. "Greece itself approaches [the poet] in the shining of earth and heaven, in the holy which conceals the god, in the poetizing-thinking being of man" (187/162). In this statement, Greece is inherently related to earth, heaven, god and man. Thus far, all the four elements of the four-fold appear. According to Heidegger, it is clear from Hölderlin's letter that these four elements "belong in a richer relation", therefore, it is no surprise that he composed a poem called "Greece". 
When discussing the four-fold in "The Thing" (1950), Heidegger is already stressing the integrity of the four, even to the point of speaking of "the simple onefold of their self-united four-fold", or "the simple oneness of the four". ${ }^{38} \mathrm{In}$ that essay, the four-fold is thematized in relation to the thinging of the thing. ${ }^{39}$ In thinging, it brings forth the four-fold of earth and heaven, gods and mortals. The four is "at one with one another of their own accord", they "belong together by way of the simpleness of the united four-fold":

Each of the four mirrors in its own way the presence of the others. Each therewith reflects itself in its own way into its own, within the simpleness of the four. This mirroring does not portray a likeness. The mirroring, lightening each of the four, appropriates [ereignet] their own presencing into simple belonging to one another. Mirroring in this appropriating-lightening way, each of the four plays to each of the others. The appropriative [ereignende] mirroring sets each of the four free into its own, but it binds these free ones into the simplicity of their essential being towards one another. (T 177/52)

It is clear that, for Heidegger, the four are not separate from one another because of their individuality as indicated by the number four. Instead, the four are bound together in their mutual differentiation in terms of mirroring appropriation (Ereignis). This text suggests the four-fold is closely related to appropriation.

In the Contributions, Heidegger states, "Grasped inceptually, the beginning is Beyng itself" (CP 41/58). In the essay "On the Beginning" (1941), he asserts, "Appropriation is Beyng", and "Beyng [is] beginning and appropriation". ${ }^{40}$ In these statements, Heidegger defines both beginning and appropriation in terms of Beyng. In the last remark, beginning and appropriation are listed together with Beyng. Because there is an essential connection between the four-fold and appropriation, and between appropriation and beginning through an essential connection between Beyng and each of the two, it is not surprising that in the essay "Hölderlin's Earth and Heaven", Heidegger relates the four-fold with beginning. We will see more details of Heidegger's exposition of earth, heaven, god and man in terms of beginning in the subsequent analysis.

With reference to another poem by Hölderlin in which he uses such words as "really/whole relation [wirkliches/ganzes Verhältnis], including the centre", Heidegger suggests that these are the names for the whole unity of the fourfold: earth and heaven, god and man. From the term "whole relation", he coins another term the "more tender in-finite relation" (EHP 187f/163). This means that earth, heaven, god and man are held together integrally from out of the centre of the full blooming relation of these four. It is important to notice already in this place that, first, the four of earth, heaven, god and man belong together in a whole relation; second, the four have an intimate relation with Greece.

V.M. Fóti rightly recognizes in Heidegger's four-fold a "containment ... of the powers of dispersal" that is present in Hölderlin's poem. For example, 
Hölderlin's cascades and the oceans fragmenting earth into far-flung archipelagos become 'tame' waters (Gewässer) supposedly sheltered by the earth. ${ }^{41}$ Fóti's observations capture well Heidegger's strong emphasis on the unitariness of the four-fold; nevertheless, she does not comment on the unique relation of the four-fold to Greece.

As in "The Thing", Heidegger here stresses the originary togetherness of the four. He comments that earth, heaven, god and man are first "caught sight of out of the intimacy of their togetherness", and that "they are already numbered in the originary sense of the tale of the 'old (scarcely heard) saying' of their togetherness" (195/170). According to Heidegger, the number four has nothing to do with a calculative sum. Rather, it refers to the self-unifying form of the in-finite relation of the "voices of destiny". In his own words,

The destiny [Geschick] would presumably be "the centre" which centres, that is, mediates, insofar as the centre first determines the four in their belonging together, sends them into their togetherness. The sending of destiny gathers the four to itself, into its centre. (EHP 195/170)

It can be seen that the number four as connected with earth, heaven, god and man has to be understood in an originary sense. It is determined as the four in the belonging together of the four, and in their being gathered into the centre, that is, the destiny. After the cited passage, Heidegger relates the terms 'destiny' and 'centre' to the term 'beginning'. He explains that the term 'beginning' does not mean an ordinary event or happening that takes place at a definite time and on a definite location. It describes an originary event in which something comes forth. Heidegger writes,

But in what manner is a beginning? A beginning is present, insofar as it remains in its coming.

For the mediation that gathers the four into the centre of their intimacy is a first coming.

Beginning remains as advent. The beginning remains all the more, the closer it keeps itself within the possibility that it can come, and in its coming brings and sends that which it keeps to itself: the in-finite relation. (EHP 195/171)

The word "beginning" delineates a mode of coming and gathering. It preserves and gathers the in-finite relation of the four to itself. Using the copula 'is', Heidegger explicitly identifies 'destiny' and 'centre' with 'beginning': "As the centre of the whole relation, destiny is the all-gathering beginning. As the ringing out of the great destiny, the centre is the great beginning" (195/171). A couple of pages later, Heidegger states, "the centre is the joint of the relation of the four" (203/179). Since "centre" is identified as "the great beginning", and grounds the intimate relation of belonging together between earth, heaven, god and man, it is reasonable to attribute a connection between 'the great beginning' and a plural form of it (beginnings) in the originary, non-calculative sense. In the meantime, it is consistent with the major line of development of Heidegger's text to treat "the few other great beginnings" as an alternative expression of the four of earth, heaven, god and man, which are closely related to Greece, and gathered together in the centre, both Greece and the centre are said to be the great beginning (200/176). 
Another claim Heidegger makes is that there must be something great to correspond to the coming of the great beginning. This great something should be able to grasp greatly the coming of the great beginning, or to wait for it greatly. The occidental, that is, the humble (das Geringe), is exactly this great something which becomes great in becoming that to which the great beginning can come. Heidegger contrasts the occidental with the oriental, which is nothing else but Greece: "The humble is the occidental. Greece, however, the oriental [das Morgenländische] is the great beginning that may possibly come" (EHP 200/176). In this passage, which has been cited in an earlier section in this paper, Greece is labelled as 'the oriental' and described as 'the great beginning'. This allows for a reading according to which it is more appropriate to associate 'the few other great beginnings' with the unique bond between the occidental and the oriental (Greece). Such a reading is more consonant with the overall concern and focus of Heidegger's essay.

With the domination of technology and industry, earth, heaven, god and man, which have appeared within occidental history as the bounded in-finite relation, have been displaced and their appearance has been denied. Following these remarks, Heidegger quotes from a letter by Paul Valéry under the title "The Crisis of the Spirit", in which two questions are posed:

This Europe, will it become what it is in reality, that is, a small cape of the Asiatic continent? Or will this Europe, rather, remain as what it appears to be, that is, the precious part of the whole earth, the pearl of the globe, the brain of a specious body? (EHP 201/177)

Heidegger comments that both of Valéry's descriptions suit the situation of contemporary Europe. While it is a mere cape, it is also the brain of the globe that manages the technological-industrial calculation. But, Heidegger says, a third question should be raised: "must Europe, as this cape and brain, first become a land of an evening from which another morning of world-destiny prepares its rise?" (201/177) Heidegger emphasizes that "our question does not pass over and beyond Europe, but back into its beginning", and that it has its ground in "an essential fact" (Wesenstatsache) on the one hand, and in "an essential supposition" (Wesensvermutung) on the other (201/177). These remarks are reminiscent of those in preceding sections of this paper. Europe, or the occidental, has to become, by retrieving its beginning in the Greek world (that is, the first beginning), the Evening-Land where the newly commenced Morning-Land, that is, the other beginning, will hopefully emerge.

In the following paragraph, Heidegger elaborates on what the essential fact and supposition consist in. This is where the phrase "the other few great beginnings" appears. For the convenience of exposition, I divide the relevant passage into two parts:

The fact consists in this: In its essential beginning, which can never be lost, the present planetary-interstellar world condition is thoroughly European-occidental-Grecian. However, the supposition reflects on this: What changes can do so only out of the reserved greatness of its beginning. Accordingly, the present world condition can receive an essential change or, for 
that matter, preparation for it, only from its beginning, which fatefully determines our age. It is the great beginning. There is, of course, no return to it. (EHP 201/177)

For Heidegger, there is an undeniable intrinsic relation between Greece, the occidental, and Europe. This is indicated by the phrase "European-occidentalGrecian". That the first great beginning occurs in Greece is an indisputable essential fact. Because of their inner bond, the present Europe can receive from this first beginning an essential change, or a preparation for the change. Since there cannot be a simplistic return to the first beginning, a re-initiation of the great beginning remains a supposition:

The great beginning becomes present, as that which awaits us, only in its coming to the humble [zum Geringen i.e. the occidental]. But the humble can no longer abide in its occidental isolation. It is opening itself up to the few other great beginnings [den wenigen anderen grossen Anfängen] that belong, with their ownness [ihrem Eigenen], in the sameness [das Selbe] of the beginning of the in-finite relation in which the earth is contained. (EHP 201/177)

The phrase "the few other great beginnings" seems to come out of the blue without any clear context, because this is the only occurrence both in "Hölderlin's Earth and Heaven" and in Heidegger's writings in general. However, if we proceed with his text with sufficient patience and care, it will not be insurmountably difficult to decipher its proper reference. We need to pay attention to the following points. First, with respect to Heidegger's saying: "But the humble can no longer abide in its occidental isolation", it should be mentioned again that the term 'occidental' is not used in contrast with the Eastern world, not to mention the East Asian world; instead, it is used in relation to the 'oriental', which denotes nothing else than Greece.

Second, the two clusters of sentences in the preceding citation parallel a pair of statements made one page earlier in Heidegger's text: "Greece, however, the oriental [das Morgenländische], is the great beginning that may possibly come. The humble is, however, only insofar as it becomes that to which the great beginning can come (EHP 200/176). The 'great beginning', that is, Greece, is what it truly is in coming to the humble; and the humble, that is, the occidental is what it truly is only in opening up itself so that the great beginning can come to it. Here we see in the second half of these two pairs of statements a clear parallel between the 'great beginning' and 'the few other great beginnings' to which the occidental is opening up. Because of the strikingly similar structure of propositions, these two terms must have a special relation. We can also speak of the latter as the plural form of the former, with the qualification that the terms plural and singular be treated in the originary sense, that is: they are intimately linked together, and their differentiation cannot be treated as a mechanistic grammatical issue.

Regarding the first half of these two pairs of statements, there is yet another paralleling statement. Just before the other statement about the humble and the great beginning, Heidegger claims that "what comes is not the god by himself alone [or any other member of this belonging relation]", but "the whole in- 
finite relation in which, along with god and mankind, earth and heaven belong" (EHP 200/175). We need to keep in mind Heidegger's characterization of earth, heaven, god and man. That is, they belong together essentially in the in-finite relation of the four. What is coming to the humble (the occidental), in one place, is said to be Greece, the great beginning. In this place, it is said to be "the whole in-finite relation" that bounds together the four of the four-fold. Here we see a parallel between the great beginning and "the whole in-finite relation" (that is, the four-fold). In yet another statement, it is said: ". . . in its coming [the beginning] brings and sends that which it keeps to itself: the in-finite relation" (EHP 195/171). In view of the intimate connection between beginning and the four of the four-fold which are embodied in the in-finite relation, in view of the conclusion of the preceding paragraph: the phrase "the few other great beginnings" to which the occidental is opening up is a variation, or, alternatively speaking, the plural form, of the "great beginning", it is strikingly obvious that the word "the few" is closely related to that of the four of the four-fold: that is, earth, heaven, god and man. Let us look at the relevant sentence again: "[The humble] is opening itself up to the few other great beginnings that belong, with their ownness, in the sameness of the beginning of the in-finite relation in which the earth is contained" (EHP 201/177). What comes after "the few other great beginnings" is a characterization that is strongly resonant with that of the four-fold we have discussed: the four of the four-fold belong together in the in-finite relation; they are brought into their ownness by appropriative movement. Among the four, earth is highlighted. This is because in this lecture, earth, in its pairing relation to heaven, is conceived as the dwelling place for the poet, as what shelters and supports the holy. ${ }^{42}$

In the paragraph immediately following the remark in which the expression "the few other great beginnings" occurs, Heidegger writes, "Yet we men of this age are presumably not even within the humbleness and neediness of that need from which the four of the in-finite relation call to each other" (201f/177). It is justifiable to claim that "the four of the in-finite relation" mentioned here refers back to "the few other great beginnings" that belong together in the in-finite relation.

Half a page later, Heidegger applies the plural form to the term "voice of destiny" when he is depicting the gloomy contemporary situation. He states, "the provocation to such making-available orders everything into a single design, the making of which levels the harmony of the in-finite relation. The togetherness of the four 'voices of destiny' no longer rings out" (202/178). This statement immediately follows the description that the harmony of the infinite relation is levelled. It is evident that the four "voices of destiny" designate earth, heaven, god and man, the four-fold whose togetherness makes up the in-finite relation. 
Through this study of Heidegger's text, I have clarified that the expression "the few other great beginnings" is completely embedded in Heidegger's thinking on the four-fold of earth, heaven, god and man, which together constitute the infinite relation. The four-fold is inseparably related to Greece, where philosophy originated in the first beginning. Since the in-finite relation refers to the fourfold of earth, heaven, god and man in their essential belongingness and self-unifying, "the few other great beginnings" can be reasonably understood as the four-fold. The numeral words "few" and "four" should be understood in the originary sense, which means that they are not ordinary numerals, but are intrinsically connected with the belongingness and self-unifying of the in-finite relation.

Furthermore, I have highlighted the numeral 'four' in order to explicate the ways in which we can reasonably connect the four of the four-fold with the 'few' of 'the few other great beginnings'. However, it should be clear that both of these phrases should be understood as both plural and singular at the same time. Just as the four-fold does not consist of independent entities, the few other great beginnings are not composed of disconnected self-standing beginnings. Just as, originarily speaking, the first beginning and the other beginning need each other to be differentiated as they are, it can be said that they designate one single event, the great beginning and the few other great beginnings intimate each other as both plural and singular at the same time. The first beginning and the great beginning are more closely connected with the epochal beginning of the history of Being in the Greek world, which grounds and makes possible the occurrence of the (few) other (great) beginnings; on the other hand, the otherness of the other beginning and the few other great beginnings is what can bring the first/great beginning into their originary truth.

\section{Conclusion}

In the passages from Heidegger's writings I have discussed, the words Morgenland, Ost, Asien, and Orient all refer to Greece. Taking these words to signify Asia, especially East Asia in the ordinary sense has given rise to incorrect interpretations of Heidegger's connection with Asian traditions. Similarly, on the basis of taking "the few other great beginnings" to be a referent to non-Western traditions, a grand conclusion is drawn with respect to Heidegger's connection with intercultural dialogue.

From the context of its appearance, it is obvious that "the few other great beginnings" has nothing to do with other philosophical traditions like East Asian thought. Instead, it refers to the four-fold of earth, heaven, god and man. Therefore, it is mistaken to read a concern with the issue of intercultural dialogue into the relevant remark. The importance that has been ascribed to "the few other great beginnings" has no textual basis at all.

According to Heidegger, in the present age, the occidental that has become Europe is characterized by technological-industrial domination. The earth has 
become an object at man's disposal. Earth and heaven as depicted in Hölderlin's poem have vanished. The in-finite relation of the four has been destroyed (EHP 200/176). However, this planetary-interstellar world condition (that is, the Ge-stell) is brought about by the denial of the in-finite relation, which is inherently connected with Greece, the Morgenland where the great/first beginning occurred. A change, or a preparation for a change, can only become possible from within the originary great beginning. In the meantime, the humble (that is, the occidental) must open up to "the few other great beginnings" that are embodied in the in-finite relation: that is, the fourfold of earth, heaven, god, and man.

These thoughts of Heidegger proceed in accordance with his consideration about the Ge-stell and about the transition into the other beginning. What makes my exposition more convincing is Heidegger's explicit association of the Ge-stell with the four-fold in one of his prefaces to "Hölderlin's Earth and Heaven". In that place he stresses that in listening to Hölderlin's poem, there must be the "transformation into the thinking experience of the centre of the in-finite relation - out of the enframing [Ge-stell] as the self-dissimulating event [Ereignis] of the four-fold" (EHP 176/153). It is Heidegger's view that one needs to think from within the Ge-stell, the present planetary world that is in a dissimulated relation with the four-fold, towards the infinite relation of the four-fold, that is, "the few other great beginnings", which is inextricably related to Greece, where the first beginning of philosophy originated.

Renmin University of China

\section{References}

1. See Lin Ma and J. van Brakel, "Heidegger's Comportment toward East-West Dialogue", Philosophy East and West 56 (4): 519-566, 2006. The general conclusion of this paper is that Heidegger's primary concern, in the context of his central tenet that Being has been forgotten and that the Ge-stell has been dominating the whole globe, is to prepare for the inception of the other beginning, which is possible because of the occurrence of the first beginning with early Greek thinkers. Because of his exacerbating worry about the Ge-stell, as well as his limited and yet sustained exposure to East Asian thought, Heidegger has entertained the idea that ancient Asian traditions, insofar as they remain unaffected by the Ge-stell, might be of help for the enactment of the other beginning.

2. Heidegger, "Anaximander's Saying", in Off the Beaten Track, trans. Julian Young (Cambridge: Cambridge University Press 2002), 242-281, p. 245; "Der Spruch des Anaximander", in Holzwege, GA 5, 1977. Henceforth A.

3. "Letter on Humanism", in Pathmarks, ed. William McNeill (Cambridge: Cambridge University Press 1998), 239-276; Wegmarken, GA 9 1976, 313-364. Henceforth LH.

4. Heidegger, "Hölderlin's Earth and Heaven", in Elucidations of Hölderlin's Poetry, trans. Keith Hoeller (Amherst NY: Humanity Books 2000), 175-207, p. 200; "Hölderlin's Himmel und Erde", in Erläuterungen zu Hölderlins Dichtung, GA 4, 1996, 152-181. Henceforth EHP. This essay originally appeared in the Hölderlin-Jahrbuch, vol. 11 (1958-60).

5. Heidegger writes in the "Letter on Humanism": "As the destiny that sends truth, Being remains concealed. But the destiny of the world is heralded in poetry, without yet becoming manifest as the history of Being. The world-historical thinking of Hölderlin that speaks out in the poem "Remembrance" is therefore essentially more primordial and thus more 
significant for the future than the mere cosmopolitanism of Goethe. For the same reason Hölderlin's relation to Greek civilization is something essentially other than humanism. (LH 258/339)

6. Peter Trawny, Heidegger und Hölderlin oder Der Europäische Morgen (Würzburg: Königshausen \& Neumann 2004), p.125.

7. Florian Vetsch, Martin Heideggers Anfang der interkulturellen Auseinandersetzung (Würzburg: Königshausen \& Neumann 1992)

8. Heidegger, "Hölderlins Dichtung ein Geschick", in Zu Hölderlin - Griechenlandreisen, GA 75 (Frankfurt am Main: Vittorio Klostermann 2000), 349-365, p. 357. Henceforth HDG. I shall discuss this passage later again in the section "The mysterious relations to the East". Here I focus on the words "the foreign" and "Morgenland".

9. In another study I have provided detailed exposition of Heidegger's discussion of "journey to the foreign". See Lin Ma, Heidegger on East-West Dialogue: Anticipating the Event (New York and London: Routledge) 2008, pp.79-89.

10. Quoted in Marco Brusotti, "Europäisch und über-Europäisch: Nietzsches Blick aus der Ferne", Tijdschrift voor Filosofie 66 (2004), 31-48, p. 47.

11. Heidegger, The Eternal Recurrence of the Same, trans. D. F. Krell, in Nietzsche, vol. II (San Francisco: Harper \& Row), 132. "Die ewige Wiederkehr des Gleichen", in Nietzsche, Band I (Pfullingen: Neske 1961), 255-472, p. 395.

12. Heidegger, Parmenides, translated by A. Schuwer and R. Rojcewicz (Bloomington: Indiana University Press, 1992); Parmenides, GA 54 (1982). Henceforth P.

13. The German original reads: "Wird dieses Abend-Land über Occident und Orient hinweg und durch das Europäische hindurch erst die Ortschaft der kommenden anfänglichen geschickten Geschichte?"

14. J.L. Mehta, "Heidegger and the comparison of Indian and Western philosophy", Philosophy East \& West 20 (1970), 303-318, p. 312. From the context of his article, it is clear that Mehta uses the word "world-historical" in the ordinary sense of the word. Also see Mehta, Martin Heidegger: The Way and the Vision (Honolulu: University of Hawaii Press 1976), 464.

15. R. Ohashi, „Heidegger und die Frage nach der abendländischen Moderne - ausgehend von einem Text Tschuang-Tses", in Thomas Buchheim, ed., Destruktion und Übersetzung: Zu den Aufgaben von Philosophiegeschichte nach Martin Heidegger (Weinheim: VCH Verlagsgesellschaft 1989), 129-139, p. 130.

16. K.K. Cho, "Der Abstieg über den Humanismus: West-Östliche Wege im Denken Heideggers", in Hans-Helmuth Gander, ed., Europa und die Philosophie (Frankfurt am Main: Vittorio Klostermann 1993), 143-174, p. 158f.

17. A similar idea is embodied in statements such as, "Does the occidental still exist? It has become Europe. Europe's technological-industrial domination has already covered the entire earth" (EHP 201/177).

18. "Das abendländische Gespräch”, in: Zu Hölderlin - Griechenlandreisen, GA 75 2000, 157196, p. 157.

19. On another occasion I have addressed the controversial event of Heidegger's engagement with Hsiao Shih-yi in an attempt to translate several verses from the Daodejing. For a discussion of Heidegger's mention of the word dao in two of his essays, and of instances of his citation from five chapters of the Daodejing in six pieces of his writings, see Lin Ma "Deciphering Heidegger's Connection with the Daodejing", Asian Philosophy 16(4) 2006, 149-171.

20. K.K. Cho, op. cit., 151.

21. Heidegger, Hölderlin's Hymn „The Ister”, trans. W. McNeill and J. Davis. Bloomington: Indiana University Press, 1996, p. 4; Hölderlin's Hymne “Der Ister”, GA 53 1983, 3. Henceforth HHI.

22. Robert Bernasconi, "On Heidegger's Other Sins of Omission", American Catholic Philosophical Quarterly 69 (2) 1995, 333-350), p. 345.

23. See Lin Ma, op. cit., pp.100-118. 
24. Heidegger, Contributions to Philosophy (From Enowinng), trans. Parvis Emad and Kenneth Maly (Bloomington: Indiana University Press 1999), 307; Beiträge zur Philosophie (Vom Ereignis), GA 65 1989, 436, henceforth CP.

25. Cf. CP $\S 85-87, \S 95-100$.

26. CP 4/5; my translation. Emad and Maly's translation "the one and only first beginning [zu dem einzig einen und ersten Anfang]" obscures the implication that there is only one first beginning.

27. J. L. Mehta, Martin Heidegger: The Way and the Vision, p.459.

28. G. Parkes, Heidegger and Asian Thought (Honolulu: University of Hawaii Press 1987).

29. G. Parkes, "Rising sun over black forest: Heidegger's Japanese connections", in Reinhard May, Heidegger's Hidden Sources: East Asian Influences on His Work, trans. G. Parkes (London: Routledge 1996), 79-117, p. 104.

30. Vetsch, op. cit., $28 \mathrm{f}$.

31. Rainer Thurnher „Der Rückgang in den Grund des Eigenen als Bedingung für ein Verstehen des Anderen im Denken Heideggers", in Hans-Helmuth Gander ed., Europa und die Philosophie (Frankfurt am Main: Vittorio Klostermann 1993), 129-141, pp. 138-39.

32. Willfred Hartig, Die Lehre des Buddha und Heidegger. Beiträge zum Ost-West-Dialog des Denkens im 20. Jahrhundert (Konstanz 1997), 19.

33. Ibid. 19.

34. Other scholars who provide similar readings of this passage include Jean Beaufret, "[no title]", in Vittorio Klostermann, Dem Andenken Martin Heideggers. Zum 26. Mai 1976 (Frankfurt am Main: Vittorio Klostermann 1977), 10-23, p. 18; Walter Strolz "Heideggers Entsprechung zum Tao-te-king und zum Zen-Buddhismus", in Sein und Nichts in der abendländischen Mystik, edited by W. Strolz, (Freiburg/Basel/Wien: Herder 1984), pp. 84, 89; Reinhard May, Heidegger's Hidden Sources: East Asian Influences on His Work, trans. Graham Parkes (London: Routledge 1996), 47f; Trawny, op. cit., 186. More recently, following Parkes's suggestion, Blocker and Starling explain "the few other great beginnings" in terms of the "multiplicity of philosophical beginnings", and regard Heidegger's remark as unequivocal evidence that he is emphasizing "the importance of the transcultural" (H. Gene, Blocker and L. Starling Christopher, Japanese Philosophy (Albany: State University of New York Press 2001, p.170f). They quote Heidegger's relevant text from the English version of May's monograph.

35. O. Pöggeler, Martin Heidegger's Path of Thinking, trans. D. Magurshak and S. Barber (Atlantic Highlands, NJ: Humanities Press International 1987), 186.

36. Pöggeler, "West-East Dialogue: Heidegger and Lao-tzu", p.68; also cf. p.56. In the same article, Pöggeler also suggests that "contrary to Hölderlin, Heidegger distinguished the Greek from the Oriental" without going into any detail (p.54).

37. R. Bernasconi, "Heidegger and the invention of the Western philosophical tradition", Journal of the British Society for Phenomenology 26 (1995), 240-254; p.250.

38. Heidegger, "The Thing", in Poetry, Language, Thought, translated by A. Hofstadter (New York: Harper 1975), 163-186, p. 176; "Das Ding”, in Vorträge und Aufsätze, Teil II, (Tübingen: Neske 1967), 37-55, p. 50, 51. Henceforth T.

39. In "The Thing", the role of Greece is not prominent. However, insofar as Heidegger's depiction of it is very similar to his account of the artwork in "The Origin of the Work of Art", which is heavily focused on Greece, Young in his article on the four-fold calls the things that thing "mini-Greek-paradigm artworks". Julian Young, "The fourfold", in Cambridge Companion to Heidegger, second edition, ed. Charles B. Guignon (Cambridge: Cambridge University Press 2006), 373-392, p. 386.

40. Heidegger, "Über den Anfang", GA 70, 16.

41. Fóti, "Mortals within the fourfold and the Hölderlinian figure of man", Philosophy Today 37(4), 1993, 392-401, p. 392.

42. According to Fóti, Heidegger's thematization of the earth, or the thing, is not unproblematic (op. cit., 398f). 